\title{
Towards la clínica de mis sueños: Findings from a needs and assets assessment among rural nurses in Chiapas, Mexico
}

\author{
Naira Arellano ${ }^{* 1,2}$, Sheila Davis ${ }^{1,2}$, Lynda Tyer-Viola ${ }^{1,2}$, Margaret M. Sullivan ${ }^{2}$, Mary E. Mihovan ${ }^{1,2}$, Katie Costa ${ }^{2}$ \\ Jafet Arrieta ${ }^{2}$, Hugo Flores ${ }^{2}$, Lindsay Palazuelos ${ }^{2}$, Daniel Palazuelos ${ }^{2}$ \\ ${ }^{1}$ MGH Institute of Health Professions School of Nursing, Boston, MA, United States \\ ${ }^{2}$ Partners In Health/Compañeros en Salud, Chiapas, Mexico
}

Received: September 20, 2014

DOI: $10.5430 /$ jnep.v5n3p90
Accepted: December 18, 2014 Online Published: January 5, 2015

URL: http://dx.doi.org/10.5430/jnep.v5n3p90

\begin{abstract}
Mexican nurses can face important challenges such as difficulty finding employment, wide ranges of salaries and strained interprofessional relationships. Additionally, many nurses in Mexico care for a marginalized and underserved patient population. In Chiapas, one of the poorest states in the country, six government-sponsored clinics have partnered with the non-profit organization Partners In Health (PIH) to deliver healthcare. The goal of this study was to explore the perceptions of the nurses employed in these clinics about their role, professional relationship with clinic doctors and about the needs and assets that characterize their work. In March of 2013, with approval from an ethical research review board, we conducted semi-structured in-depth interviews with the eight clinic nurses and six doctors working alongside them. The qualitative data analysis showed that nurses highlighted their role in disease prevention, reported highly valuing collaboration with clinic doctors and wanted opportunities to expand their clinical knowledge. Nurses identified the burden of documentation and lack of preparation for medical emergencies among their biggest professional challenges. These findings will serve as the foundation for the strategy to be used to support the work of nurses in the PIH-supported clinics.
\end{abstract}

Key Words: Nursing, Rural health services, Mexico, Needs assessment

\section{Introduction}

\subsection{Nursing in Mexico}

About $45 \%$ of the Mexican health care workforce consists of nurses. ${ }^{[1]}$ However, there are high dropout rates from nursing school and low employment rates among nurses who graduate from university-level nursing programs. ${ }^{[2]}$ Given that largely public resources support health care provider education in Mexico, the limited gains from this investment are troublesome because of the large number of Mexicans who have inadequate access to health care. ${ }^{[2]}$ For example, a study from 2006 reported that at the national level, half of the patients with hypertension did not receive a health care intervention. ${ }^{[3]}$ Yet there is evidence that nurse-led case management of cardiovascular disease can accomplish a variety of positive health outcomes. ${ }^{[4]}$ An improved understanding of the challenges and opportunities faced by Mexican nurses can help strengthen this crucial sector of the country's health care workforce. Nevertheless, the full potential of nurses on primary care delivery in lowresource settings remains understudied. In Mexico, most of the nursing workforce research has been focused on hospital nurses. ${ }^{[5,6]}$ More broadly, the current global shortage of human resources for health (HRH) underscores the need to explore avenues to support the nursing workforce world-

*Correspondence: Naira Arellano; Email: nairaarellano@gmail.com; Address: 1820 S. Throop St. Apt 2F, Chicago, IL 60608, United States. 
wide. The Global Health Workforce Alliance states that low motivation, low retention, and insufficient training of health workers aggravates the HRH crisis. ${ }^{[7]}$ In this context, it is critical to gear efforts towards improved nurse satisfaction, retention rates, and continuous training to prevent further HRH loses and optimize the functioning of these essential health workers.

\subsection{Profile of Chiapas, Mexico}

According to the Pan American Health Organization, a third of the 100 most disadvantaged municipalities in Mexico are concentrated in the state of Chiapas. ${ }^{[8]}$ Stark disparities exist between these municipalities and the national average. The risk of child mortality under the age of one is almost two times higher than the national average. ${ }^{[8]}$ Life expectancy for both men (49 years) and women (51 years) is over two decades shorter than the national average. ${ }^{[8]}$ For over two decades, the non-profit organization Partners In Health (PIH) has had an established presence in Chiapas. In 2011, PIH launched the sister organization Compañeros en Salud (CES) to strengthen the health care system of the Chiapas Sierra by working with government-run rural clinics where health care services are provided by nurses employed by the Ministry of Health and by doctors recruited by CES to complete their social service requirement (pasantía) in the region. In the Sierra, living conditions are difficult, with approximately $30 \%$ of homes lacking water, $46 \%$ lacking sewage, and $15 \%$ lacking electricity. ${ }^{[9]}$ At the time of the study, CES supported the functioning of six rural clinics with a catchment area of around 12,000 and approximately 1,800 monthly patient visits. While pasantes typically remain in the clinics only for the duration of their social service year, nurses may work in the clinics for years to decades. Nurses also spend up to ten days a month providing care independently while pasantes attend trainings and have time off. In collaboration with US-based medical residents, CES is implementing an academic model to train pasantes on primary care, global health, and social medicine. To complement this program and to understand the work of the rural nurses better, CES worked with a team of US-based volunteer nurse practitioners and nurse practitioner students to carry out a nursing needs and assets assessment in March 2013. This team interviewed the nurses and pasantes working in CES-supported clinics. Analysis of these qualitative data provided a unique insight into the work of nurses and doctors. The purpose of this assessment was to provide the foundation for a plan to support the work of nurses in the CES clinics and to contribute to the understanding of the work of rural nurses in Latin America.

\section{Methods}

We conducted this study in March 2013 with approval from the Partners Human Research Committee IRB. A semistructured interview was designed in collaboration with the CES team, taking into consideration the landscape of Mexican nursing and nursing workforce studies conducted outside of Mexico. ${ }^{[10,11]}$ The interview team was comprised of two Family Nurse Practitioners and two Registered Nurses/Nurse Practitioner students with demonstrated Spanish-English bilingual competency. The interviewers were divided in teams of two and each team covered three clinics based on geographic location. CES staff members visited the clinics in advance to invite nurses and doctors to participate in the needs and assets assessment voluntarily and to ask for consent to audio record the interviews. The interviewers confirmed consent upon arrival. The interviewers spent up to eight hours shadowing the nurses and then administered the questions orally one-on-one in Spanish during clinic downtime. The interviews were audio recorded in order to ensure validity of the data. Full names and clinic locations were not recorded to protect confidentiality.

\subsection{Sample}

Eight nurses and six doctors working at the six CESsupported rural clinics in Chiapas were interviewed (see Table 1).

Table 1: Selected demographic characteristic of sample

\begin{tabular}{lll}
\hline & $\begin{array}{l}\text { Nurses Interviewed (N = 8) } \\
\text { N (\%) }\end{array}$ & $\begin{array}{l}\text { Doctors Interviewed (N = 6) } \\
\text { N (\%) }\end{array}$ \\
\hline Gender & $7(87.5)$ & $4(66.6)$ \\
Female & $1(12.5)$ & $2(33.3)$ \\
Male & 33.4 & 25 \\
Mean Age (yrs) & & $6(100)$ \\
Time working in CES clinic & $0(0)$ & \\
Less than 1 year & $3(37.5)$ & \\
1-3 years & $2(25)$ & \\
4-7 years & $1(12.5)$ & \\
8-10 years & $2(25)$ & \\
11 years or more & & \\
\hline
\end{tabular}




\subsection{Data analysis}

The team of interviewers held an audio recorded debriefing session to discuss the themes that emerged during each of their interviews. After the group debriefing, the first author listened to the interviews and the group debriefing session and compiled a list of the collectively identified themes and direct quotes that best illustrated those themes. The coauthors reviewed this list and agreed on a final compilation of predominant themes.

As shown in Table 1, both nurses and doctors interviewed were predominantly female. Nurses and doctors differed in their mean age and time working in the rural clinic, both of which were greater among nurses.

\section{Results}

\subsection{Predominant themes and supporting partici- pant quotations}

\subsubsection{Motivators and deterrents of working as a nurse}

Themes that emerged when asking nurses about their professional motivation included a desire to help people and being inspired by watching nurses at work in the communities where they grew up.

"Creo que todos los días, siempre, hay una persona que nos necesita" [I think that every day, always, there is someone who needs us] - Nurse

Conversely, several nurses reported facing strong family opposition to their career choice. Nurses attributed this lack of support to their families' perception of higher education as something suitable only for men and fear that young women leaving the community to study were in reality intending to find a husband and become pregnant.

\subsubsection{Nurses' perception of their role}

Nurses identified the following responsibilities when we inquired about their role in the clinic: 1) administering vaccinations, 2) well-checks of patients enrolled in a government conditional cash-transfer program, 3) triage of patients presenting for sick visits, 4) family planning, 5) health education talks, 6) prenatal care and care of the newborn, and 7) medical emergencies. Nurses highlighted the importance of their role in health promotion and disease prevention efforts.

“Más que curativos somos preventivos" [More than treatment, what we provide is prevention] - Nurse

\subsubsection{Nurse-Doctor relationship}

When asked to discuss the nurse-doctor relationship, nurses identified strong communication and keeping the doctor informed of nursing activities as factors that contributed to a good working relationship. Conversely, nurses reported that when they perceived a doctor lacked interest in the nurse's daily clinic duties the relationship was negatively affected. Doctors spoke of the importance of clinical staff spending time together outside the clinic, for example going for walks and sharing meals, as a strategy that promoted a stronger nurse-doctor relationship.

\subsubsection{Needs and assets}

In an effort to elicit constructive feedback, nurses and doctors were asked to imagine and describe how they envisioned the clinic of their dreams (la clinica de sus sueños) and how this clinic compared with their current workplace. This exercise, adapted from a tool by The Constellation for AIDS Competence, ${ }^{[12]}$ facilitated a discussion of what the nurses and doctors see as their needs and assets. A predominant theme that emerged among nurses was the desire to expand their clinical knowledge and skills. Doctors also identified further training for nurses as a need and as a factor that would allow nurses to be more involved in the management of uncomplicated medical conditions at the clinic.

"No soy médico [..] pero siempre me gusta saber lo que un médico sabe" [I am not a doctor, but I always like to know what a doctor knows]-Nurse

"Aparte de pasar los pacientes estar ahí con el-
los, porque me gusta ver cómo es que atienden
a los pacientes y el diagnositcar" [Aside from
just bringing the patient inside, [I would like to]
be in there with them because I like to see how
patients receive care and are diagnosed]-Nurse

Some of the main challenges identified by nurses included working in a space not conducive to patient privacy, the heavy burden of documentation, and dearth of resources and preparation to handle medical emergencies.

"Si una paciente tiene una urgencia [..] viene (a la clínica) y no pregunta si está el médico o si es el enfermero o la enfermera [..] ellos vienen confiados de que se les va a ayudar, de que si tú estás aquí es porque tienes el conocimiento y puedes ayudarlos [..] Para mí eso es un desafio porque yo no sé en qué momento me voy a encontrar con algo que no pueda solucionar" [If a patient has an emergency [..] she comes (to the clinic) and doesn't ask if the doctor is there or if it is the nurse who is in [..] they come trusting that they will be helped, that if you are there it is because you have the knowledge and can help them [..] for me that is a challenge because I don't know when I am going to face something I cannot address]-Nurse 
The main asset identified by nurses and doctors was human capital. Interviewees placed a strong value on teamwork and collaboration in their clinics. Both nurses and doctors reported preferring to work with each other than alone and identified the absence of either nurse or doctor as a challenge.

"When she is around the clinic I do believe that we make a very good team. I really like working with her [..] But when she is not around the relationship breaks a little bit"-Doctor

"Era más complicado para nosotras [trabajar sin el pasante] porque teníamos que ver todo. Ya no eramos ni enfermeras, eramos todólogas" [It was more complicated for us [working without the pasante] because we had to take care of everything. We were not even nurses, we did it all]-Nurse

\section{Conclusions}

Further research is needed to continue exploring the challenges and opportunities that characterize the work of nurses in rural Mexico. It is also very important to put lessons learned into practice. We will begin addressing the predominant themes that emerged in this study by developing a strategy to support the work of nurses in CES-supported clinics. We plan to begin by targeting three main objectives in the CES-supported clinics: 1) facilitate communication between nurses and doctors by encouraging adoption of regular clinic huddles/meetings, 2) provide mentorship from local and foreign nurses, and 3) support the nurses' desire to further their clinical knowledge and bolster interprofessional collaboration by engaging nurses and doctors in team-based learning and allocation of clinical tasks that complement each other. Our team-based learning strategy is grounded on the Care Delivery Value Chain approach. ${ }^{[13]}$ This novel framework of health care delivery takes into consideration the full chain of interdependent inputs and actions necessary to produce a high value outcome for patients. ${ }^{[13]}$ Finally, we will foster nursing leadership by encouraging the emergence of local nurse-champion(s) to help maintain a collaborative relationship between the clinic nurses, CES and the Ministry of Health. Investing in the professional growth of nurses in rural Mexico is essential to strengthen their role in the health care system and to support the care of the marginalized populations they serve.

\section{Acknowledgements}

The authors would like to thank the Chiapanecan communities for warmly welcoming the interviewers during their visit. The authors would also like to acknowledge the invaluable support of the MGH Institute of Health Professions, which financed the travel of the two MGH Institute of Health Professions students who were part of the team of interviewers.

\section{Conflicts of Interest Disclosure}

The author declares that there is no conflict of interest statement.

\section{References}

[1] Squires A. The North American Free Trade agreement (NAFTA) and Mexican nursing. Health Policy and Plan. 2010 Mar; 26(2): 124132. PMid: 20595330 http://dx.doi.org/10.1093/heapol/ czq024

[2] Nigenda, G, Ruiz JA, Rosales Y, Bejarano R. Enfermeras con licenciatura en México: estimación de los niveles de deserción escolar y desperdicio laboral. Salud Pública Mex. 2006 Jan-Feb; 48(1): 22-9. Available from: http://www.scielo.org.mx/pdf/spm/ $\mathrm{v} 48 \mathrm{n} 1 / \mathrm{v} 48 \mathrm{n} 1 \mathrm{a} 05 . \mathrm{pdf}$

[3] Lozano R, Soliz P, Gakidou E, et al. Benchmarking of performance of Mexican states with effective coverage. Lancet. 2006 Nov 11; 368(9548): 1729-41. PMid: 17098091

[4] Berra K, Miller NH, Jennings C. Nurse-based models for cardiovascular disease prevention: from research to practice. J Cardiovasc Nurs. 2011 Jul-Aug; 26(4 Suppl): S46-55. PMid: 21762851 http://dx.doi.org/10.1097/JCN.0b013e318213ef5c

[5] Squires A, Juarez, A. A qualitative study of the work environments of Mexican nurses. Int J Nurs Stud. 2012 Jul; 49(7): 793-802. PMid: 22386989 http://dx.doi.org/10.1016/j.ijnurstu.2012.02.001

[6] Hernández-Zavala M, Hernández-Cantoral A, Nava-Galán MG, et al. Satisfacción laboral del profesional de enfermería en cuatro instituciones de salud. Enfermeriia Universitaria ENEO-UNAM. 2012 Jan-Mar; 9(1): 7-15. Available from: http://www.scielo.org.m $\mathrm{x} / \mathrm{pdf} / \mathrm{eu} / \mathrm{v} 9 \mathrm{n} 1 / \mathrm{v} 9 \mathrm{n} 1 \mathrm{a} 2 . \mathrm{pdf}$

[7] Global Health Workforce Alliance. 2012 Annual Report: Making Health Workers Count. Geneva, Switzerland: Global Health

Published by Sciedu Press
Workforce Alliance/World Health Organization, 2012. Available from: http://www. who.int/workforcealliance/knowledg e/resources/annualreport2012/en/

[8] Pan American Health Association. Health in the Americas, 2012 Edition: Country Volume, Mexico. Washington, DC: Pan American Health Association/World Health Organization, 2012. Available from: http: //www.paho.org/saludenlasamericas/index.php?op tion=com_docman\&task=doc_view\&gid=137\&Itemid=

[9] Instituto para el Federalismo y el Desarrollo Municipal. Estado de Chiapas. In: Enciclopedia de los Municipios y Delegaciones de México. México, DF: Secretaria de Gobernación, 2010. Available from: http://www.inafed.gob.mx/work/enciclopedi a/EMM07chiapas/

[10] Hallin K, Danielson E. Registered nurses' experiences of daily work, a balance between strain and stimulation: A qualitative study. International Journal of Nursing Studies. 2007 Sept; 44(7): 1221-30. PMid: 16844126. http://dx.doi.org/10.1016/j.ijnurstu. 2006.05.011

[11] Hallin K, Danielson E. Registered nurses' perceptions of their work and professional development. J Adv Nurs. 2008 Jan; 61(1): 62-70. PMid: 18034817

[12] The Constellation for AIDS Competence. 3-steps of Creating a Community Vision/Dream. Belgium: The Constellation for AIDS Competence, 2012. Available from: http://www. communitylif ecompetence.org/en/94-resources

[13] Kim JY, Farmer P, Porter ME. Redefining global health-care delivery. Lancet. 2013. PMid: $23697823 \mathrm{http}: / / \mathrm{dx}$.doi.org/10.10 $16 / \mathrm{S} 0140-6736$ (13) $61047-8$ 